\title{
WOMEN REFUGEES: EMPOWERMENT AND VULNERABILITY
}

\author{
Helene Moussa, O.I.S.E.
}

Much of the literature on women refugees depicts them as victims and as vulnerable because they are women. They are portrayed as being passive and dependent with limited abilities to survive, cope and adapt. This perception in turn hinders chances for resettlement in countries such as Canada because the expectation is that refugees, like immigrants, will become economically independent and adjust in a relatively short period of time. Focusing on vulnerability places the problem on women rather than on the aggression perpetrated against them because they are women.

As I listened to and reflected on the life journeys of women refugees, I was deeply moved by their strength and courage, their determination to survive, to maintain their identities and integrity, and to struggle to fulfil life goals. Their concern for the future of their country and peoples also awed me. I came to recognize their actions as forms of resistance. This understanding has made me see them as victimized rather than as victims, and as shapers of their personal and collective lives. These women have, in effect, challenged state power, violence, and persecution, in their decisions to flee their homes and country.

Flight journey experiences differed in terms of routes taken and the people with whom they fled. The age range of women at the time of flight was 14-36. All married women fled without their spouses. All children fled with their mothers. Most single women travelled alone or with a group of strangers. A few fled with a close relative or friends. Women who travelled overland did so with the assistance of guides (nomads) or The Eritrean Peoples Liberation Front (EPLF) or the Tigrayan Peoples Liberation Front (TPLF) militants. Only one woman had ever travelled outside of Ethiopia prior to flight.

Whatever the route and whomever they travelled with, women took many risks. To be caught fleeing the country is an act of betrayal under the Ethiopian Criminal Code. The punishment is imprisonment with hard labour from 525 years. Those fleeing overland risked being caught in the war zones.

These women usually travelled by night to avoid being bombed by the Ethiopian air force. One of the many hazards of night travel was falling prey to wild animals. Rape was another actual and/or potential risk, in flight, as well as upon arrival at borders.

In retrospect, however, all the women interviewed felt that even if they had been conscious of these risks before leaving their homes, they would have made the same decision. One woman said:

I would not have believed that it was any more dangerous than the violence I experienced daily in my neighbourhood. At the beginning you think you will not make it, but once you accept the hardships you can look forward to your safe arrival at your destination.

All women experience fears and risks during flight, but all said that the decision to leave their homes revealed their strength and ability to challenge socially prescribed dependency roles. This was expressed succinctly by one woman who said:

I learned that I could make decisions alone and take risks that I would never have realized I was capable of as a woman. Before, all major decisions in my life would be taken by my family.

All women, however, felt that the price for this insight was too high to value the experience in and of itself. Enforced separations under state repression, the terror that engulfed their lives prior to flight, and the experience of becoming refugees are experiences with which many still have to come to terms.

\section{SEXUAL ABUSE}

While African states such as Sudan have been noted for their open door and non-refoulement policies with regards to refugees, the experiences of women fleeing to Sudan and Djibouti were intermingled with the encounter of the status of women in Islamic culture and the double bind of being womenrefugees.

Prior to flight, torture and sexual assault was an actual and/or imminent experience whether women were imprisoned or not. Those who lived in war zones were also at risk. In flight and in asylum, women's search for safety does not end when they leave Ethiopian borders. One woman stated that,

You have to belong to a man ...There is no way to have protection as a woman alone. Because a woman travels alone it is proof that she is a prostitute.

She further described the gender differences within the limited protection refugees have in asylum:

I was walking with [her husband] when a man stopped us and started feeling my arms and my shoulders. [Her husband] wanted to fight him but I stopped him because we have no rights as refugees. He would be jailed and then I wouldn't have any protection.

Single women described their powerlessness as women and how they tried to link themselves with others so that they would never be walking alone in the streets. Some women get married for the sole purpose of being "protected" by a male. One woman said that she never left the house of the family she stayed with for the six months she waited for papers that allowed her to fly to Italy. In Djibouti-ville, women pointed out that women must be accompanied by a man, preferably several men, when they register at the UNHCR Office.

The plight of women refugees in Djibouti has received little attention. Roberta Aitchison described the horrifying experiences of rape in exchange of "safe passage" across the border, the direct complicity of guards in refugee camps and police in the city of Dibouti-ville. According to those I interviewed, the situation of women refugees has not changed. 
The situation of Ethiopian women (and men) in Djibouti was exacerbated by the Somali-Ethiopian War (1977) and continuing tensions between the two states. They may have been refugees, but they also represented "the enemy." Women in my study had a very clear understanding of the differences in the types of violence perpetrated against

$$
\begin{aligned}
& \text {...described the horrifying } \\
& \text { experiences of rape in } \\
& \text { exchange of "safe passage" } \\
& \text { across the border, the direct } \\
& \text { complicity of guards in } \\
& \text { refugee camps and police in } \\
& \text { the city of Djibouti-ville. }
\end{aligned}
$$

men and women who arrived at the border. Men were beaten up, imprisoned and threatened with repatriation. Women were also threatened with repatriation. They, however, had to submit to the sexual demands of guards if they were to be permitted to cross the border. Those women who were jailed then had to face multiple rapes. Often women are "employed" as servants where they have to provide sexual "services." Women who were sent to refugee camps were also vulnerable to rape even if they were accompanied by husbands, relatives or male companions.

Many women who managed to live in Djibouti-ville have resorted to prostitution both as a means of survival and as a way of controlling their lives. One woman reported:

Women who have been raped are so bitter. One of them said "why shouldn't I be paid rather than let myself be raped?" ... they have no feelings left in their body and they are very bitter about their future.

She also described how these women would financially assist other refugees who had no means of support. One of her best memories was how "everyone helped anyone in need." Women were very supportive of each other, "because we could understand why women became prostitutes and if we were not raped we knew that it could happen to us at any time." One of the worst fears of women who were raped was that they would bear a child. Abortions are illegal and the health consequences of side-street abortions can be very serious.

Women related stories of situations where women were "forced" to marry nomadic tribesmen. They accept because they are safer that way. There is this girl who lived for two years with a nomad. She accepted their ways and even had two children. One day she went to the UNHCR Office and spoke in English. Everyone was surprised.

Another woman who was a refugee in Djibouti pointed out that the French navy and army are the major "customers" of refugees who have become prostitutes. Some of these women are able to live with a military man while he is stationed in Djibouti. This semblance of stability is not long lasting. Once the military are transferred, women are abandoned. One woman also admitted that women refugees were "used by our own people. Some men (refugees) are pimps."

In 1980 a Tripartite Commission, which included representatives from the UNHCR, the Ethiopian and the Djibouti governments, was established to examine the voluntary repatriation of Ethiopian refugees in Djibouti. While there has been a great deal of criticism about the manner in which refugees "volunteered" and the actual safety afforded to Ethiopian refugees upon return, there is no mention about the implications of this agreement on women who have experienced rape or resorted to prostitution as a desperate means of survival. These women could never return to their home towns or villages for the following reasons:

Sexin our culture is not for enjoyment, it's to have children. It's a big shame to lose your virginity outside of marriage. So they lose their dignity when they are prostitutes and/or raped.

Reflecting on her experience another woman in my study said:

Idon't want to remember. I have seen the worst. Now I am safe. I am happy. But I can't forget when I think of all the women who were not as lucky as me and who are still in Djibouti. I wish there was a way to help them.

Chances for these women to resettle in the West, particularly if they have no family, are slim. Women I spoke with were torn between a sense of responsibility and a sense of powerlessness to relieve the plight of women refugees in Djibouti.

\section{POLITICIZATION}

Despite the dangers of fleeing through war zones, women who fled with the assistance of the EPLF and TPLF were challenged to consider their role in society by the efforts of these movements to reach more equitable gender relations, the development potentials of their
As I listened to and reflected on the life journeys of women refugees, I was deeply moved by their strength and courage, their determination to survive, to maintain their identities and integrity, and to struggle to fulfil life goals.

peoples and the depth of political commitment of the liberation movement members. One woman said that the journey had challenged her to reflect on her class formation.

Eritrean and Tigrayan women were very much aware of war in their regions. Indeed a major reason for their flight was the effects of these wars on their lives and the persecution they and their families experienced because of their national identities. They were, however, surprised to see development projects in liberated areas. Not only were they impressed to see the underground hospitals, small factories, and fruit and vegetable farms, but as one woman put it, "I realized that if a human being has the will anything is possible." This realization not only helped her endure the hardships of becoming a refugee but also influenced her determination to "make something of my life once I was safe." 
The flight through liberated areas was instrumental in politicizing these women. One woman observed:

Until then I was not good in politics. I know something now because of what I learned and what I saw in the liberated areas and from discussions with the liberation fighters.

Women noted development of a new consciousness of women and men. In liberated areas of Eritrea and Tigray, women saw the actualization of the potential of women and conscious efforts of both men and women to change the socially prescribed subordinate roles of women. They were surprised to see

- that women had the right to own and cultivate land;

- that literacy programmes were arenas for husbands and wives to discuss the status of women;

- that both movements had education programmes to curtail the practice of female circumcision;

- that the minimum age of marriage was 16 years and that consent of both partners was an expected; and

- that women were trained in nontraditional trades as well as in professional roles.

If some women had earlier ambivalences about gender values with respect to their personal experiences, family and community relations, this ambivalence now shifted to the role women can play towards changing society. The experience also challenged them to actively support the struggles of their people once they were resettled in Canada. Some, for instance, speak in public forums and others help raise funds and material aid for war orphans and hunger relief.

Those who fled through liberated areas were particularly impressed with the stamina of women militants:

I learned a lot. Specially in terms of women. It's unbelievable what women do. I heard about women I knew how strong they became physically and psychologically. They can be just eating kollo [a porridge] and wheat but they are so physically strong... As a woman I learned that there is nothing that prohibits women as a female..... they walk for four days and then they fight! ...

You know the land is redistributed and peasants, even women including widows and single mothers can now own land.... There is nothing to block them. I always believed that I could achieve anything mentally like a man, but I learned a lot from them. It made me realize that I can contribute to changing the conditions of my people.

Women are active in the military and administrative activities of both the EPLF and the TPLF. The bravery of women fighters and their role in the struggle impressed another woman in her flight journey:

Women have a very important role in the liberation movement. When I was with the fighters it was amazing to see how the women were teaching. They were more active than the men! Almost half the fighters were women. They were brave and even encouraged the men! I was surprised. I saw women as front line fighters.

This is a major shift in gender consciousness since, as early as 1943 during an earlier rebellion in Tigray province (the Weyene rebellion), war prisoners, spies and collaborators were dressed-up as women and paraded in the markets to be ridiculed for being as weak as women. Women in Ethiopia,

\section{If some women had earlier ambivalences about gender values with respect to their personal experiences, family and community relations, this ambivalence now shifted to the role women can play towards changing society.}

however, took part in warfare even prior to the Italo-Ethiopia war (1935.) They also took up arms on the eve of the ItaloEthiopian war despite a decree prohibiting them from enlisting. Tsehai Berhane Silassie argues that this law silenced women's participation in Ethiopian history and in the consciousness of the present generation. Nevertheless, women in the liberation struggles have become role models because of their courage and dedication to the betterment of their people. One of them concluded, "all this makes me believe that one is not born for our selfish needs but to contribute to society."

Hardships of flight made one woman reflect on her class values:

On this trip we met peasants and we lived like them. They were so generous. They shared the little food they had, and if they did not have food they would go to neighbours. We ate like them. Even the water that was full of worms and insects. I got an awareness that we are equal as human beings. Money, status and even education does not mean everything. The poor gave us what they had... What is in your heart is the most important thing. The peasants had a better life. We were living a false life. Wedid not have a cent when my father left the fled the country ahead of his children because of impending imprisonment] I learned what it means to suffer. I was so bourgeois at home that I would even ask a servant to bring me a glass of water...How could Ibe living in Ethiopia and Eritrea and be so detached?

Women's experiences before becoming refugees, in flight and during asylum, will differ and will inevitably impact upon their adjustment process. More importantly however, these experiences can lead to empowerment through a process of politicization and self-awareness, as well as disempowerment (as a result of brutality and violence) - and as is generally depicted in available literature on women refugees.

The experience of being a refugee tends to involve a process of identity formation in terms of discontinuities, continuities, resistance and identity reconstruction. Viewed from this perspective, one should expect that refugee women who have experienced this process of empowerment will become functional, highly-motivated members of society after resettlement in countries such as Canada.

(Helene Moussa is a doctoral candidate at the Ontario Institute for Studies in Education, Toronto, Canada.) 